Article

\title{
Similar Safety Profile of the Enantiomeric N-Aminoalkyl Derivatives of \\ Trans-2-Aminocyclohexan-1-ol Demonstrating Anticonvulsant Activity
}

\author{
Karolina Słoczyńska@, Paulina Koczurkiewicz *, Kamil Piska, Beata Powroźnik, \\ Katarzyna Wójcik-Pszczoła, Katarzyna Klaś, Magdalena Wyszkowska-Kolatko and \\ Elżbieta Pękala \\ Department of Pharmaceutical Biochemistry, Faculty of Pharmacy, Jagiellonian University Medical College, \\ 9 Medyczna Street, 30-688 Krakow, Poland \\ * Correspondence: paulina.koczurkiewicz@uj.edu.pl; Tel.: +48-12-620-55-77
}

Received: 25 June 2019; Accepted: 9 July 2019; Published: 9 July 2019

\begin{abstract}
Epilepsy is one of the most common neurological disorder in the world. Many antiepileptic drugs cause multiple adverse effects. Moreover, multidrug resistance is a serious problem in epilepsy treatment. In the present study we evaluated the safety profile of three (1-3) new chiral $\mathrm{N}$-aminoalkyl derivatives of trans-2-aminocyclohexan-1-ol demonstrating anticonvulsant activity. Our aim was also to determine differences between the enantiomeric compounds with respect to their safety profile. The results of the study indicated that compounds 1-3 are non-cytotoxic for astrocytes, although they exhibit cytotoxic activity against human glioblastoma cells. Moreover, 1-3 did not affect the viability of HepG2 cells and did not produce adducts with glutathione. Compounds 1-3 demonstrated no mutagenic activity either in the Salmonella typhimurium or in Vibrio harveyi tests. Additionally, the compounds displayed a strong or moderate antimutagenic effect. Finally, the P-glycoprotein (P-gp) ATPase assay demonstrated that both enantiomers are potent P-gp inhibitors. To sum up, our results indicate that the newly synthesized derivatives may be considered promising candidates for further research on anticonvulsant drug discovery and development. Our study indicated the similar safety profile of the enantiomeric $\mathrm{N}$-aminoalkyl derivatives of trans-2-aminocyclohexan-1-ol, although in the previous studies both enantiomers differ in their biotransformation pathways and pharmacological activity.
\end{abstract}

Keywords: aminocyclohexanol; cytotoxicity; enantiomers; epilepsy; mutagenicity; P-glycoprotein

\section{Introduction}

Epilepsy is one of the most common neurological disorder in the world. Despite advanced studies on antiepileptic therapies, there is still a lack of effective drugs that are appropriate for patients. The most important challenges in epilepsy treatment include the multiple and serious adverse effects of the currently available antiepileptic drugs (AEDs) and multidrug resistance (MDR) [1-5].

In the search for new agents that possess antiepileptic activity, we turned our attention to aminocyclohexanol derivatives that exhibit potent central nervous system (CNS) activity [6-8]. In the previous study we described the synthesis, in vivo anticonvulsant activity, and in vitro metabolism of three new chiral $\mathrm{N}$-aminoalkyl derivatives of trans-2-aminocyclohexan-1-ol, denoted as $\mathbf{1}$ ( $R$ enantiomer), 2 (S enantiomer), and 3 (racemate) (Figure 1) [9]. These compounds were proved to be active anticonvulsants in a maximal electroshock test (MES) performed at the National Institute of Health (Rockville, USA) within the Antiepileptic Drug Development Program [10]. In particular, $R$ enantiomer 
exhibited anti-MES activity with a protective index (PI) of 1.72 (mice, i.p.), whereas racemate showed PI value of 2.83 (mice, i.p.) (Table 1) [9]. Moreover, biotransformation analysis of compounds 1-3 performed in the liver microsome system demonstrated that enantiomers $R$ and $S$ undergo different biotransformation pathways, which could explain their therapeutic potential and toxicity [9].

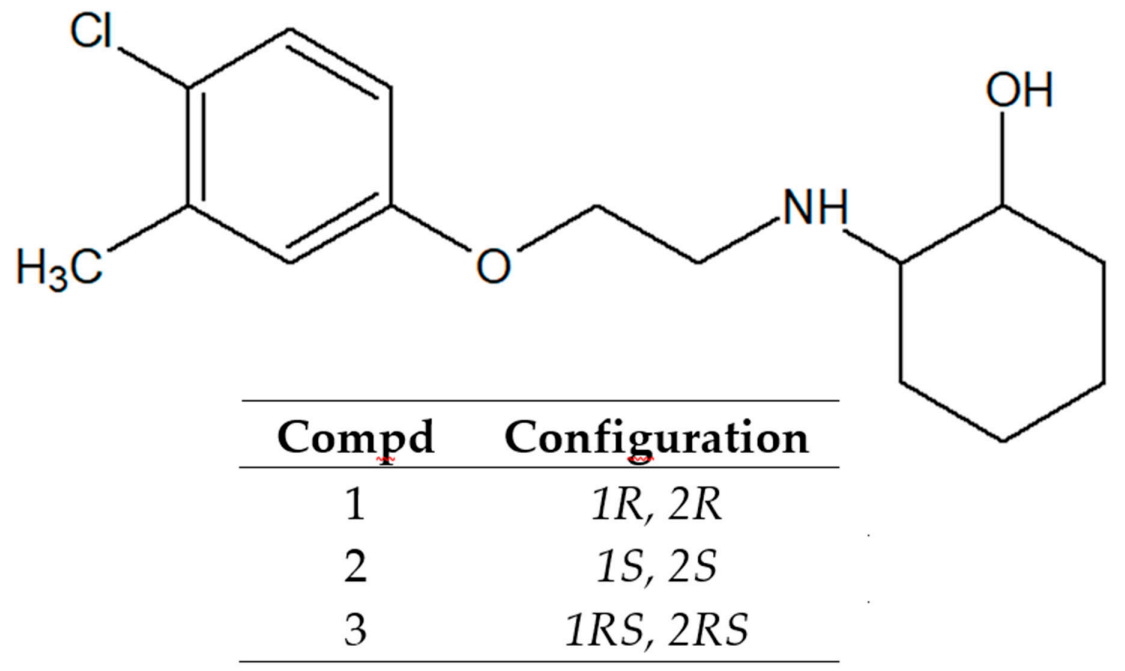

Figure 1. Chemical structures of the title compounds (1-3).

Table 1. Anticonvulsant quantification results (in vivo study) [9].

\begin{tabular}{|c|c|c|c|c|}
\hline Compound & Dose (mg/kg) & $\mathrm{TD}_{50}{ }^{\mathrm{a}}$ & ED50 $_{\text {(MES) }} b$ & $\mathbf{P I}_{\text {(MES) }}$ \\
\hline \multirow{2}{*}{1} & 30 & $66.03^{\#}$ & $38.34^{\#}$ & $1.722^{\#}$ \\
\hline & 100 & $66.03^{\#}{ }_{\text {scMet }}$ & $>90.00{ }^{\#}{ }_{\mathrm{scMet}}$ & $<1.722{ }^{\#}{ }_{\text {scMet }}$ \\
\hline \multirow{3}{*}{2} & 30 & n.d. & n.d. & n.d. \\
\hline & 100 & n.d. & n.d. & n.d. \\
\hline & 30 & $71.04^{\#}$ & $25.05^{\#}$ & $2.839 \#$ \\
\hline \multirow[t]{2}{*}{3} & 100 & $71.04^{\#}{ }_{\text {scMet }}$ & $>150^{\#}{ }_{\text {scMet }}$ & $<0.474{ }^{\#}{ }_{\text {scMet }}$ \\
\hline & 300 & $>250^{\wedge}$ & $99.25^{\wedge}$ & $2.519^{\wedge}$ \\
\hline \multirow{2}{*}{ PHT } & & $34.45^{\#}$ & $6.48^{\#}$ & $6.60^{\#}$ \\
\hline & & $>500^{\wedge}$ & $32.2^{\wedge}$ & $>22^{\wedge}$ \\
\hline \multirow{2}{*}{ CBZ } & & $47.8^{\#}$ & $9.85^{\#}$ & $4.90^{\#}$ \\
\hline & & $361^{\wedge}$ & $3.57^{\wedge}$ & $101^{\wedge}$ \\
\hline \multirow{2}{*}{ VPA } & & $483^{\#}$ & $287^{\#}$ & $1.70^{\#}$ \\
\hline & & $859^{\wedge}$ & $395^{\wedge}$ & $2.2^{\wedge}$ \\
\hline
\end{tabular}

${ }^{\mathrm{a}}$ Dose of the compound that produces toxicity in $50 \%$ of tested animals; ${ }^{\mathrm{b}}$ dose of the compound that gives protection against seizures toxicity in $50 \%$ of tested animals. ${ }^{\#}$ Values for mice after i.p. administration. ${ }^{\wedge}$ Values for rats after p.o. administration; n.d.—not determined. Anticonvulsant quantification were determined only for compounds $\mathbf{1}$ and 3, which display sufficient antiepileptic activity and low neurotoxicity in the primary evaluations; PHT: phenytoin, BZ: carbamazepine, VPA: valproate.

In light of the aforementioned findings and continuing our study of three active chiral $N$-aminoalkyl derivatives of trans-2-aminocyclohexan-1-ol, the present work was focused on in vitro cytotoxicity evaluation and understanding the basic mechanisms that underlie compounds 1-3 activity. In particular, we established the safety profile of $\mathbf{1}-\mathbf{3}$ by performing cellular cytotoxicity analysis using CNS cells and mutagenicity assays with the bacterial strains Salmonella typhimurium and Vibrio harveyi. As many AEDs are known to demonstrate hepatotoxic effects, we also evaluated the hepatotoxicity of compounds 1-3, both in a HepG2 cellular model and in a human liver microsome system in the presence of glutathione. Additionally, the antimutagenic effects of test substances were determined.

MDR has been described in many patients receiving anticonvulsant treatment. One frequently described mechanism of this phenomenon is overexpression of ATP-binding cassette (ABC) transporters at the blood-brain barrier. High ABC transporter expression is largely responsible for the fact that 
anticonvulsant drugs are pumped out of their target site of action [11]. P-glycoprotein $(P$-gp $)$ plays a crucial role in drug absorption and brain uptake, and many studies have demonstrated that several AEDs could be P-gp substrates or inhibitors [5,12-15]. Therefore, within the present paper, the ability of compounds 1-3 to modulate P-gp ATPase activity was assessed to clarify the interactions between the investigated compounds and P-gp and to evaluate their potential as new drug candidates for treating MDR epilepsy.

Finally, our aim was to determine differences between the enantiomeric $N$-aminoalkyl derivatives of trans-2-aminocyclohexan-1-ol with respect to their safety profile.

\section{Results and Discussion}

\subsection{Cytotoxicity}

AEDs are fraught with numerous undesirable effects, of which cytotoxicity is one of the most serious [16-20]. Therefore, in this work we focused our attention on assessing the active compounds' (1-3) cytotoxicity in relation to CNS cells. A typical model for neurotoxicity evaluation commonly used in publications are human neuroblastoma SH-SY5Y cells. Considering the fact that the cells of this line are transformed, they have a cancerous origin. Therefore, within this work we decided to investigate the safety profile of compounds 1-3 on a normal cell line i.e., astrocytes. Astrocytes are specialized glial cells that contiguously tile the entire central nervous system and play a crucial role in CNS [21]. Interestingly, astrocytes are also vulnerable to seizures, as shown by Gualtieri et al. [22] and reviewed in Curia et al. [23]. Moreover, astrocytes have been used successfully in safety profile analysis of different compounds [24-27].

The results obtained using the MTT assay demonstrated that none of the tested compounds induced a significant cytotoxic effect on the normal astrocyte cell line in a concentration range of 10-100 $\mu \mathrm{M}$, while glioblastoma cells incubated with higher concentrations of both enantiomers lose viability in a dose-dependent manner (Figure 2). The racemic compound was less cytotoxic than the two enantiomers. Moreover, the results of the MTT test are comparable with those obtained in the LDH assay (Figure 3). Matysiak et al., who examined the cytotoxicity of $(R)$ - and (S)-ricinoleic acid amides and their acetates, revealed that both enantiomers of the ethanolamine-derived amides showed promising anticancer potential [28]. On the other hand, in the study of praziquantel enantiomers it was indicated that both enantiomers differ in their cytotoxicity profile [29]. Similarly, according to Tokunaga et al. the enantiomeric forms of fluoro-thalidomide displayed different anti-tumor activities, with the (S)-enantiomer being noticeably more potent [30].

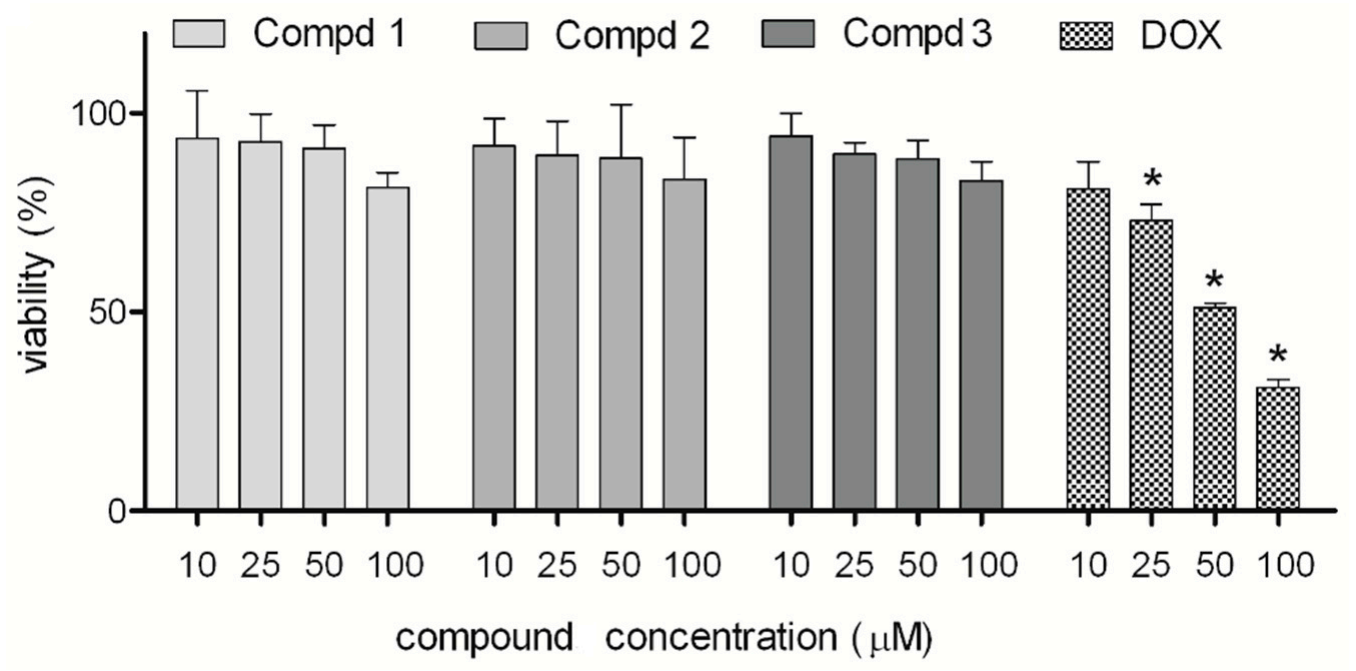

(a)

Figure 2. Cont. 


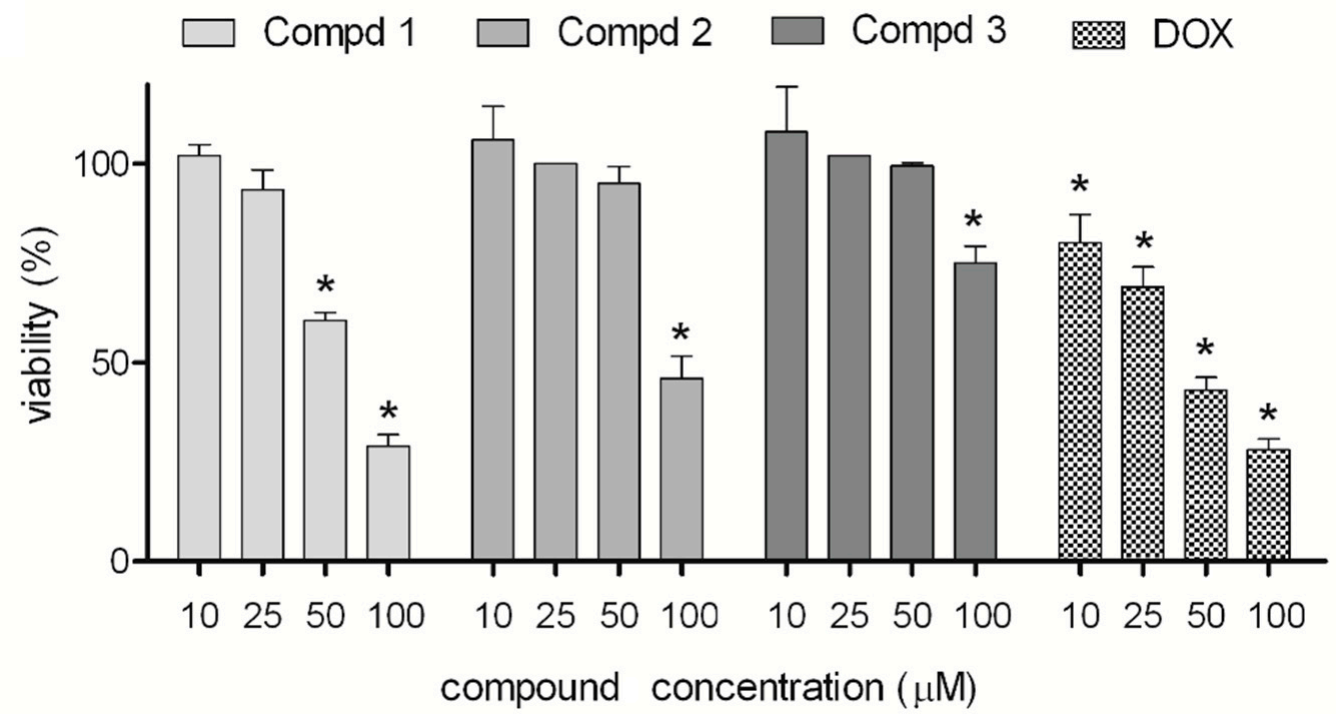

(b)

Figure 2. Effect of compounds 1, 2, and 3 on viability of astrocytes (a) and human glioma cells (b). Cells were cultured in medium supplemented with 10\% FBS and antibiotics in the presence or absence (control) of compounds (10, 25, 50, or $100 \mu \mathrm{M})$. After $24 \mathrm{~h}$ incubation, the MTT assay was performed. Doxorubicin (DOX) was used as a positive control. Results from the MTT assay are presented as percent of living cells compared to the control. Values represent means \pm SEM of three independent experiments $(p<0.05)$.

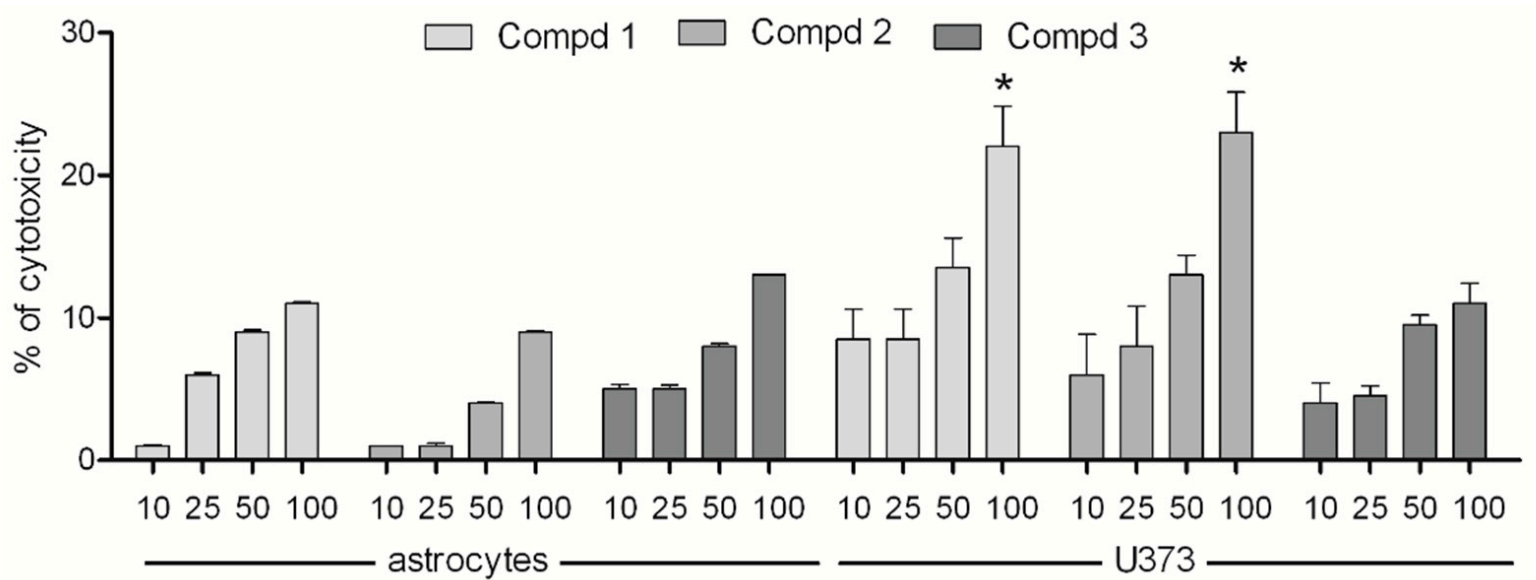

Figure 3. Cytotoxicity of compounds 1, 2, and 3 on astrocytes and human glioma cells. Cells were cultured in medium supplemented with $10 \%$ FBS and antibiotics in the presence of compounds (10, 25, 50 , or $100 \mu \mathrm{M})$. Results from LDH assays show the percent of cytotoxicity compared to the control. Values represent means \pm SEM of three independent experiments $(p<0.05)$.

The observed selectivity of $\mathbf{1 - 3}$ towards different cell lines is particularly interesting and opens up new prospects for research on their activity. Cytotoxic activity of tested trans-2-aminocyclohexan-1-ol derivatives with chiral carbon atoms against tumor cells may be vital in the context of their potential chemopreventive action. The anti-cancer activity of anti-epileptic drugs has previously been described in the literature; however, there have been no reports concerning compound selectivity. Interestingly, valproic acid prodrug was used to increase the sensitivity of neoplastic cells to doxorubicin therapy [31]. In another study, Kwiecińska et al. demonstrated that co-treatment with valproic acid increased the efficiency of doxorubicin, carboplatin, and cyclophosphamide in various ovarian cancer cell lines [32]. 


\subsection{Hepatotoxicity, Metabolic Activation and Trapping Assay}

Drug-induced liver injury is the most common cause of liver injury and a serious clinical problem. Therefore, within the present paper compounds 1-3 were evaluated in vitro for their hepatotoxicity on human liver cancer cells (HepG2) in the MTT viability assay. As shown in Figure 4, the tested compounds did not affect the viability of HepG2 cells at concentrations up to $100 \mu \mathrm{M}$. Moreover, they did not affect the cellular morphology after $24 \mathrm{~h}$ incubation, even at the highest concentration used in the experiment (Figure 4).
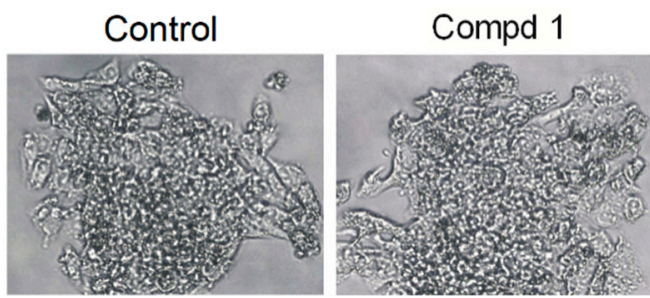

Compd 2

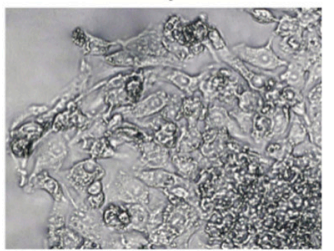

Compd 3

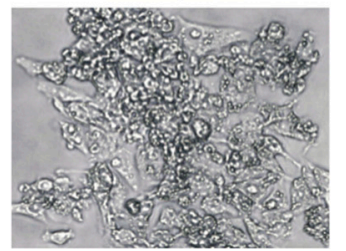

(a)

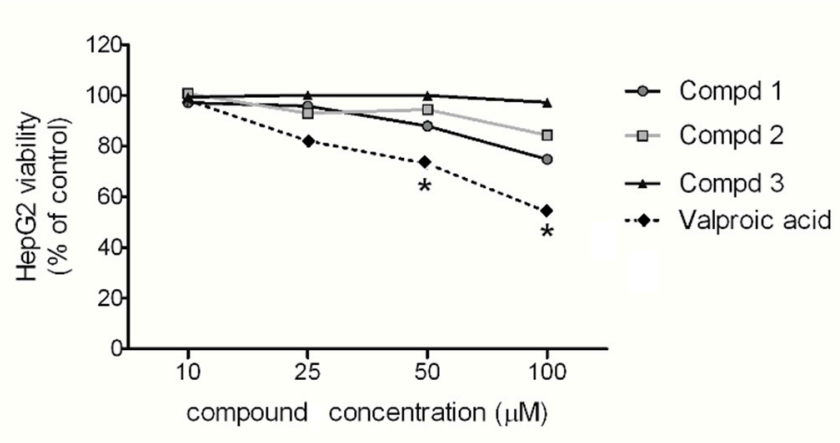

(b)

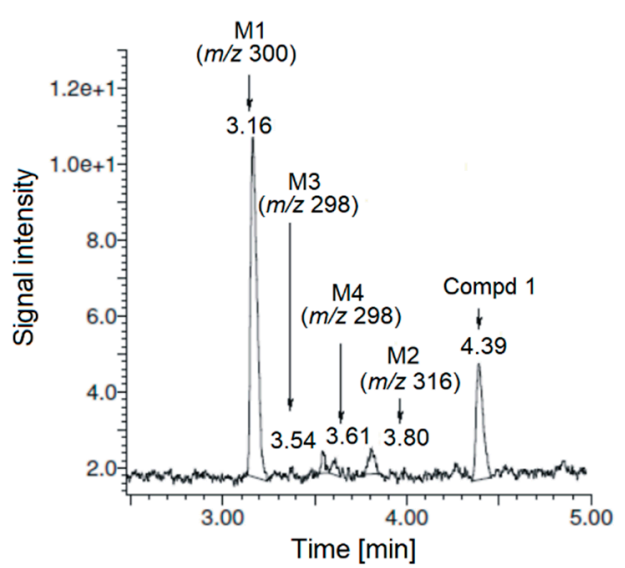

(c)

Figure 4. Hepatotoxicity of 1, 2, and 3. Cells were cultured in medium supplemented with $10 \%$ FBS in the absence or presence of compounds $(10,25,50$, or $100 \mu \mathrm{M})$. After $24 \mathrm{~h}$ incubation, pictures of cells were taken using bright field microscope (a) and the MTT assay (b) was performed. Results from the MTT assay show the percent of living (metabolically active) cells. Values represent means \pm SEM of three independent experiments $(p<0.05)$. Valproic acid was used as positive control. Metabolic activation and trapping assay (c); representative chromatogram of $\mathbf{1}$ and its metabolites following incubation of 1 with human liver microsomes supplemented with NADPH and reduced glutathione. Molecular masses of the $[\mathrm{M}+\mathrm{H}]^{+}$ions of metabolites are shown.

Many xenobiotics are known to display hepatotoxic activity, resulting not only from their direct action, but also from their biotransformation to reactive intermediates [33,34]. Such properties are characteristic of classical AEDs, such as valproic acid, which is biotransformed to a toxic metabolite 4-ene-valproic acid. The hepatotoxicity of 4-ene-valproic acid contributes to the development of liver injury [35]. Electrophiles that occur during metabolism form conjugates with intracellular macromolecules and constituents of the antioxidant system (primarily with glutathione); this causes its depletion and contributes to hepatocytes necrosis. For these reasons, early drug development processes include strategies for the detection of reactive metabolites by means of trapping assays with glutathione [36-38].

Compounds 1-3 were examined for the production of toxic metabolites in order to predict their hepatotoxic potential. Incubations of test compounds with glutathione gave several peaks that were attributed entirely to the remaining parent compound. The main metabolites were the products of aliphatic hydroxylation ( $m / z$ 300) and carbonylation ( $m / z 298$ and $m / z 316)$ (Figure 5). The representative 
chromatogram of $R$ enantiomer and its metabolites following incubation with human liver microsomes (HLMs) supplemented with NADPH and glutathione is presented in Figure 4. As compounds 1-3 did not produce any adducts with glutathione in the human liver microsome system, probably they can be classified as safe with respect to their metabolic fate. These results are consistent with previous reports relating to in vitro biotransformation of compounds 1-3 with rat liver microsomes [9].<smiles>O=Cc1cc(OCCNC2CCCCC2O)ccc1Cl</smiles>

Figure 5. Chemical structures of the main metabolites of compounds 1-3.

\subsection{Mutagenicity and Antimutagenicity}

Mutagenic activity is one of the most important endpoints for risk assessment of chemical compounds including both drug substances and drug candidates. Mutagenic agents are capable of inducing unfavorable effects on genetic material of a cell [39]. As regards chiral compounds, enantiomers may possess different carcinogenicity and teratogenicity [40]. On the other hand, the mutagenic properties of some chemicals may be partly modulated or reduced by using agents possessing antimutagenic activity [41].

In the present paper, mutagenicity and antimutagenicity of 1-3 were evaluated using two microbial systems i.e., Salmonella typhimurium and Vibrio harveyi. According to our findings, the racemic compound and both enantiomers demonstrated no mutagenic activity either in the TA100 strain of $S$. typhimurium or in the strains of $V$. harveyi (BB7, BB7M, BB7X, and BB7XM) (Tables 2 and 3). Additionally, the investigated compounds displayed a strong or moderate antimutagenic effect on chemically induced mutagenesis in S. typhimurium and $V$. harveyi strains (Tables 2 and 3). To determine the antimutagenic activity, a direct mutagen nitroquinoline-N-oxide (NQNO) was used. NQNO is a base substitution agent, principally acting on G residues, inducing mainly GC to AT transitions [42]. The observed protection of the bacterial genome against NQNO damage may be a result of the inhibition of the interaction between DNA and a mutagen [41,43]. However, more studies are needed to confirm this hypothesis. 
Table 2. Mutagenic activity of tested compounds in the Ames and the Vibrio harveyi tests.

\begin{tabular}{|c|c|c|c|c|c|c|c|c|c|c|}
\hline \multirow{3}{*}{ Compound } & \multirow{2}{*}{\multicolumn{2}{|c|}{$\begin{array}{c}\text { Ames Test } \\
\text { TA100 }^{\mathrm{a}}\end{array}$}} & \multicolumn{8}{|c|}{ Vibrio harveyi Test } \\
\hline & & & \multicolumn{2}{|c|}{ BB7 ${ }^{\mathrm{a}}$} & \multicolumn{2}{|c|}{ BB7X $^{a}$} & \multicolumn{2}{|c|}{ BB7M $^{a}$} & \multicolumn{2}{|c|}{ BB7XM $^{a}$} \\
\hline & Mean \pm SD & $\mathrm{MI}^{\mathrm{b}}$ & Mean \pm SD & $\mathrm{MI}^{\mathrm{b}}$ & Mean \pm SD & $\mathrm{MI}^{\mathrm{b}}$ & Mean \pm SD & MI $^{b}$ & Mean \pm SD & $\mathbf{M I}^{\mathrm{b}}$ \\
\hline $\mathrm{H}_{2} \mathrm{O}$ & $8 \pm 3$ & & $19 \pm 4$ & & $17 \pm 6$ & & $22 \pm 3$ & & $9 \pm 4$ & \\
\hline DMSO & $16 \pm 5$ & & $16 \pm 3$ & & $13 \pm 4$ & & $16 \pm 2$ & & $11 \pm 4$ & \\
\hline NQNO & $33 \pm 4$ & 2.1 & $32 \pm 4$ & 2.0 & $26 \pm 2$ & 2.0 & $32 \pm 2$ & 2.0 & $24 \pm 3$ & 2.2 \\
\hline 1 & $9 \pm 4$ & 0.6 & $21 \pm 3$ & 1.1 & $16 \pm 5$ & 0.9 & $22 \pm 3$ & 1.0 & $18 \pm 2$ & 1.6 \\
\hline 2 & $3 \pm 1$ & 0.2 & $23 \pm 5$ & 1.2 & $10 \pm 6$ & 0.6 & $23 \pm 3$ & 1.1 & $10 \pm 3$ & 0.9 \\
\hline 3 & $6 \pm 3$ & 0.4 & $23 \pm 3$ & 1.4 & $13 \pm 4$ & 1.0 & $27 \pm 4$ & 1.7 & $15 \pm 4$ & 1.4 \\
\hline
\end{tabular}

${ }^{\mathrm{a}}$ Number of revertants; $\mathrm{NQNO}$ (nitroquinoline- $\mathrm{N}$-oxide, $40 \mathrm{ng} / \mathrm{mL}$ ) was used as a positive control; DMSO and $\mathrm{H}_{2} \mathrm{O}$ were used as a negative control; ${ }^{\mathrm{b}} \mathrm{MI}$ (mutagenic index): number of induced revertants/number of spontaneous revertants (positive assay when $\mathrm{MI} \geq 2$ ).

Table 3. Antimutagenic activity of compounds 1-3 in the Ames and the Vibrio harveyi tests.

\begin{tabular}{|c|c|c|c|c|c|c|c|c|c|c|}
\hline \multirow{3}{*}{ Compound } & \multirow{2}{*}{\multicolumn{2}{|c|}{$\begin{array}{c}\text { Ames Test } \\
\text { TA100 }^{a}\end{array}$}} & \multicolumn{8}{|c|}{ Vibrio harveyi Test } \\
\hline & & & \multicolumn{2}{|c|}{ BB7 ${ }^{a}$} & \multicolumn{2}{|c|}{ BB7X $^{a}$} & \multicolumn{2}{|c|}{ BB7M $^{a}$} & \multicolumn{2}{|c|}{ BB7XM $^{a}$} \\
\hline & Mean \pm SD & Inhib. $(\%)^{b}$ & Mean \pm SD & Inhib. (\%) ${ }^{b}$ & Mean \pm SD & Inhib. $(\%)^{b}$ & Mean \pm SD & Inhib. $(\%)^{b}$ & Mean \pm SD & Inhib. (\%) ${ }^{b}$ \\
\hline $\mathrm{H}_{2} \mathrm{O}$ & $5 \pm 2$ & & $12 \pm 2$ & & $11 \pm 4$ & & $16 \pm 3$ & & $13 \pm 4$ & \\
\hline DMSO & $6 \pm 2$ & & $14 \pm 3$ & & $13 \pm 3$ & & $10 \pm 2$ & & $15 \pm 3$ & \\
\hline NQNO & $22 \pm 4$ & & $38 \pm 5$ & & $29 \pm 4$ & & $35 \pm 3$ & & $24 \pm 4$ & \\
\hline 1 & $16 \pm 2$ & $(27)$ & $26 \pm 3$ & (32) & $20 \pm 4$ & (31) & $22 \pm 2$ & (37) & $16 \pm 2$ & (35) \\
\hline 2 & $14 \pm 3$ & (38) & $23 \pm 4$ & (38) & $21 \pm 3$ & (30) & $20 \pm 4$ & $(41)$ & $14 \pm 4$ & $(40)$ \\
\hline 3 & $13 \pm 3$ & $(41)$ & $19 \pm 3$ & (51) & $21 \pm 4$ & (29) & $22 \pm 5$ & (36) & $10 \pm 4$ & (57) \\
\hline
\end{tabular}

a Number of revertants; $\mathrm{NQNO}$ (nitroquinoline- $\mathrm{N}$-oxide, $40 \mathrm{ng} / \mathrm{mL}$ ) was used as a positive control; DMSO and $\mathrm{H}_{2} \mathrm{O}$ were used as a negative control; ${ }^{\mathrm{b}}$ the values in parenthesis are the inhibition rates (\%) of mutagenicity; $25-40 \%$ inhibition: moderate antigenotoxicity, $40 \%$; or more inhibition: strong antigenotoxicity, $25 \%$ or less inhibition: no antigenotoxicity. 


\subsection{P-gp Activity}

An important approach in the evaluation of 1-3 was to determine their interaction with P-gp, which is an integral plasma membrane protein and functions as an ATP-dependent drug efflux pump [44,45]. It was demonstrated that P-gp is involved in MDR and some adverse drug-drug interactions [46,47]. P-gp-interacting pharmaceutical agents are recognized as stimulators or inhibitors of ATPase activity.

In the present experiment, verapamil (VER), which is an inhibitor as well as a substrate of P-gp, was used as a positive control that stimulates P-gp ATPase activity (ATP consumption) [44]. In the presence of VER a P-gp-dependent decrease in luminescence was observed, whereas in the case of two enantiomers, an increase in luminescence was detected, which indicates a decrease in ATPase activity and, thus, inhibition of the P-gp ATPase function (Figure 6). Therefore, it was demonstrated that both enantiomers possess P-gp inhibition ability, with $R$ enantiomer being more potent. It was demonstrated previously that P-gp can interact in a different way with enantiomers [48-50]. When chiral drugs modulate P-gp, one enantiomer can increase the activity of the pump, while the other enantiomer can inhibit its activity [51,52].

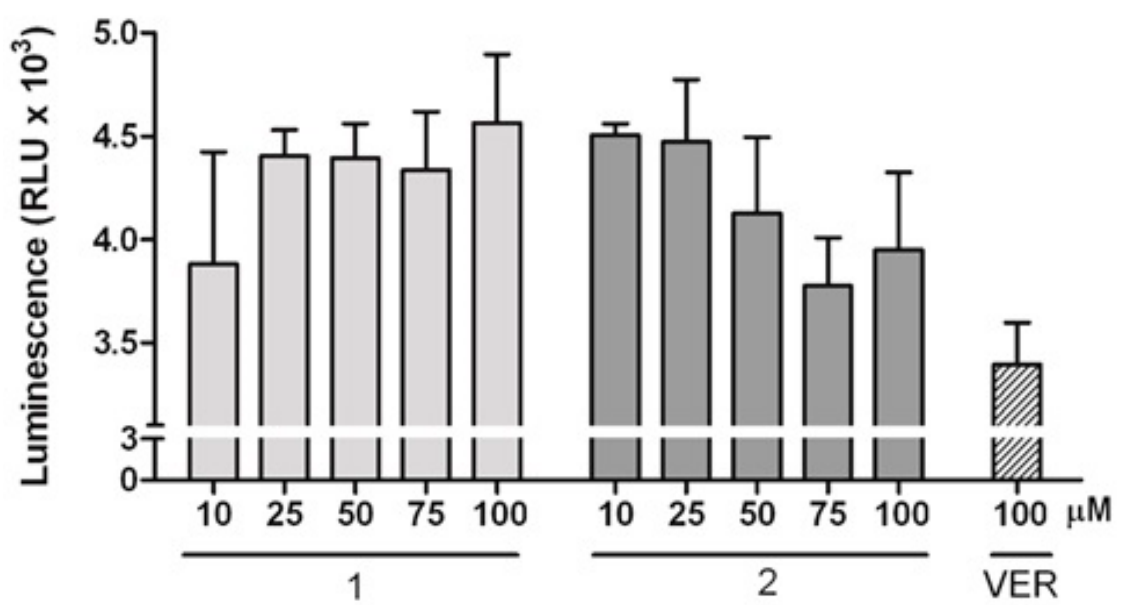

Figure 6. Effects of $\mathbf{1}$ or $\mathbf{2}$ and verapamil (VER) on P-gp activity. P-gp ATPase activity was determined by using the P-gp-Glo TM assay system, and ATP accumulation was measured as luminescence in a cellular system in the absence and in the presence of $100 \mu \mathrm{M}$ verapamil (used as positive control for ATPase activity inhibition) or 1 or 2 at increasing concentrations $(10,25,50,75$, or $100 \mu \mathrm{M})$.

In general, P-gp inhibition is related to three mechanisms: drug binding site blocking, influence on ATP hydrolysis, and modification of membrane lipid integrity [15]. Interestingly, such inhibition of P-gp may represent an approach to improving treatment efficiency, especially in the field of oncology or pharmacoresistant epilepsy [14,53-58]. As regards both tested enantiomers, further studies are definitely needed in order to better understand their P-gp inhibition potential and possible MDR modulation potency.

\section{Materials and Methods}

\subsection{Cytotoxicity Assays}

\subsubsection{Cell Culture}

Astrocyte cell line (ATCC, CRL-2541), human glioblastoma astrocytoma cell line U373 (ATCC, HTB17-1055), and human hepatoma HepG2 cells (ATCC, HB-8065) were used in the study. The cells were cultured in standard conditions $\left(37^{\circ} \mathrm{C}, 5 \% \mathrm{CO}_{2}\right)$, in EMEM medium with $2 \mathrm{mM}$ glutamine and $1 \%$ non-essential amino acids, all supplemented with $10 \%$ FBS and antibiotics (penicillin-streptomycin; $10,000 \mathrm{U} / \mathrm{mL}$; final concentration in culture medium was $1 \%$ ). 


\subsubsection{MTT Viability Test}

The cells were seeded at a density of $1 \times 10^{4}$ in 96 -well plates. Following overnight culture, the cells were treated with increasing doses of compounds 1-3 (i.e., 10, 25, 50, or $100 \mu \mathrm{M}$ ) and incubated for $24 \mathrm{~h}$. Next, $10 \mu \mathrm{L}$ of MTT (3-(4,5-dimethylthiazolyl-2)-2,5-diphenyltetrazolium bromide) reagent (Cayman) was added to each well and after $3 \mathrm{~h}$ of incubation $\left(37^{\circ} \mathrm{C}, 5 \% \mathrm{CO}_{2}\right)$ the medium was aspirated, and the formazan produced in the cells appeared as dark crystals at the bottom of the wells. Subsequently, crystal dissolving solution (Cayman) was added to each well and the optical density (OD) was determined at $570 \mathrm{~nm}$ on a plate reader (BIOTEK). Doxorubicin (DOX) was used as a positive control. When hepatotoxicity of test compounds was evaluated, the morphology of the cells was also determined using a bright-field inverted microscope (Nikon).

\subsubsection{LDH Viability Test}

The cells were seeded at a density of $1 \times 10^{4}$ in 96-well plates. Following overnight culture, the cells were treated with increasing doses of 1-3 (i.e., 10, 25, 50, or $100 \mu \mathrm{M}$ ) and incubated for $24 \mathrm{~h}$. Subsequently, $100 \mu \mathrm{L}$ of cell supernatant was transferred to a new 96 -well plate and $100 \mu \mathrm{l}$ of a reaction solution (Cayman) was added to each well. Cells were incubated for $30 \mathrm{~min}$ at $37^{\circ} \mathrm{C}$ and absorbance was measured at $490 \mathrm{~nm}$. The percent of cytotoxicity of the test samples was determined according to the following formula: ((experimental value A490) - (spontaneous release))/((maximum release) (spontaneous release) $) \times 100 \%$, where spontaneous release is the absorbance origin from the control cells, and maximum release is the absorbance origin from the cells treated with TRITON-X-100.

\subsubsection{Data Analysis}

Data from the cytotoxicity assays were analyzed using Mann-Whitney U test with GraphPad Prism 4.0 Software (GraphPad Software Inc., San Diego, CA, USA). Values of $p<0.05$ were considered to be statistically significant.

\subsection{Metabolic Activation and Trapping Assay}

\subsubsection{Chemicals and Reagents}

Human liver microsomes (HLMs), NADPH-regenerating system components, and reduced glutathione were purchased from Sigma-Aldrich (St Louis, MO, USA).

\subsubsection{Human Liver Microsomal Biotransformation and Trapping Assay}

The reaction systems (total volume of $250 \mu \mathrm{L}$ ) contained compounds 1, 2, or $3(50 \mu \mathrm{M})$, glutathione ( $1 \mathrm{mM}), \mathrm{HLMs}(1 \mathrm{mg} / \mathrm{mL})$, NADPH-regenerating system, and $0.1 \mathrm{M}$ potassium phosphate buffer ( $\mathrm{pH} 7.4)$. After $10 \mathrm{~min}$ preincubation at $37^{\circ} \mathrm{C}$, the reaction was started by adding the NADPH-regenerating system (NADP, glucose-6-phosphate, and glucose-6-phosphate dehydrogenase in a potassium phosphate buffer). Incubation was conducted for $60 \mathrm{~min}$ at $37{ }^{\circ} \mathrm{C}$ in a shaker. Then $70 \%$ perchloric acid was used to terminate the reaction. After centrifugation at 10,000 rpm for $10 \mathrm{~min}$, the supernatant was collected and analyzed by UPLC-MS/MS (Waters Corporation, Milford, MA, USA) for direct analysis of glutathione adducts. Control reactions were carried out in the absence of glutathione. All probes were done in duplicate [59].

\subsection{Mutagenicity and Antimutagenicity Assays}

\subsubsection{Chemicals and Reagents}

The following chemicals and reagents were obtained from Sigma-Aldrich (St Louis, MO, USA): magnesium sulfate, citric acid monohydrate, potassium phosphate dibasic, sodium ammonium phosphate, L-histidine, D-biotin, sodium phosphate dibasic, sodium phosphate monobasic, magnesium chloride, potassium chloride, and 4-nitroquinoline- $N$-oxide (NQNO). Agar, bacto-peptone, and beef 
extract were purchased from Merck (Darmstadt, Germany). D-Glucose, NaCl, and DMSO were obtained from Chempur (Piekary Śląskie, Poland), and nutrient broth no. 2 from Oxoid (Hampshire, UK). Glycerol and neomycin sulfate were purchased from Pharma Cosmetic (Krakow, Poland).

\subsubsection{Bacterial Test Systems}

S. typhimurium TA100 strain was kindly provided by Dr. K.I. Sugiyama (National Institute of Hygienic Sciences, Tokyo, Japan); V. harveyi strains were a gift from Prof. G. Wegrzyn (Department of Molecular Biology, University of Gdańsk, Poland).

\subsubsection{Ames Mutagenicity Testing}

The Ames assay was conducted by the preincubation method using S. typhimurium TA100 strain [60]. Each probe was performed in triplicate; $100 \mu \mathrm{L}$ of the overnight bacterial culture, $50 \mu \mathrm{L}$ of the investigated compounds at a concentration of $40 \mathrm{ng} / \mathrm{mL}$, and $500 \mu \mathrm{L}$ of a buffer solution were preincubated for $30 \mathrm{~min}$ at $37^{\circ} \mathrm{C}$ and then added to $2 \mathrm{~mL}$ of the top agar containing histidine/biotin solution. The resulting mixture was poured onto minimal glucose plates. After $48 \mathrm{~h}$ incubation, the revertants were counted manually and the results were expressed as mutagenic index (MI) $(\mathrm{MI}=$ the number of revertant colonies induced in the tested sample/the number of spontaneous revertants in the negative control). The mutagenic potential of a test compound was stated if the mutant frequency was 2.0 or higher $[61,62]$. The standard mutagen used as a positive control was NQNO. DMSO served as the negative (solvent) control.

\subsubsection{Vibrio harveyi Mutagenicity Testing}

In the experiment, overnight cultures of bacterial strains BB7, BB7M, BB7X, and BB7XM were used. Each culture was centrifuged and $10 \mu \mathrm{L}$ of $V$. harveyi pellets was placed in $20 \mathrm{~mL}$ of BOSS medium. The culture was cultivated at $30^{\circ} \mathrm{C}$ until the optical density reached 0.1 at $600 \mathrm{~nm}\left(\mathrm{OD}_{600}\right)$. Then, $10 \mu \mathrm{L}$ of test compound solution (final concentration of $40 \mathrm{ng} / \mathrm{mL}$ ) was added to the bacterial culture and incubated. Incubation was continued until $\mathrm{OD}_{600}$ reached $0.3-0.4$. Next, $5 \times 10^{6}$ bacterial cells were spread onto BOSS agar plates with neomycin. The plates were incubated at $30{ }^{\circ} \mathrm{C}$ for $48 \mathrm{~h}$ and the number of neomycin-resistant colonies was counted. As a positive control, NQNO was used, whereas DMSO and water served as negative controls [63-65]. All the experiments were analyzed in three independent repetitions. Finally, MI was calculated. A compound was considered mutagenic if MI was equal or greater than $2.0[61,62]$.

\subsubsection{Ames Antimutagenicity Testing}

The antimutagenic properties of compounds 1-3 were assayed in S. typhimurium TA100 strain against NQNO with a modified method of Maron and Ames [60].

Triplicate plates were set up with each test compound concentration and the entire experiment was repeated twice. The inhibition of mutagenicity was expressed as a percentage decrease of reverse mutation, calculated using the following equation: percent inhibition $=100-\left(\left(R_{1} / R_{2}\right) \times 100\right)$, where $R_{1}$ is the number of revertants per plate induced by test compound plus mutagen, and $R_{2}$ is the number of revertants per plate induced by a mutagen alone; $25-40 \%$ inhibition was defined as moderate antimutagenicity, $40 \%$ or higher inhibition was defined as strong antimutagenicity, and $25 \%$ or less inhibition indicated no antimutagenicity $[66,67]$.

\subsubsection{Vibrio harveyi Antimutagenicity Testing}

The antimutagenicity assay was conducted according to the same procedure as used for the mutagenicity assay, except that the standard mutagen was also added to the bacterial cultures incubated with test compounds [65]. The inhibition percentage of mutagenicity was calculated as described above in the Ames antimutagenicity assay procedure. 


\subsection{P-gp ATPase Activity Assay}

The changes in the ATPase activity of P-gp were determined by using the P-gp-Glo TM assay system (Promega). Verapamil (VER) was used as a positive control since it inhibits P-gp ATPase activity, which eventually leads to reduced drug efflux. When P-gp ATPase activity is inhibited, ATP accumulates and becomes a substrate for luciferase, with a consequent increase in luminescence. The tested compounds at increasing concentration $(10-100 \mu \mathrm{M})$ were incubated with $5 \mathrm{mM} \mathrm{Mg}$ ATP and $25 \mu \mathrm{g}$ recombinant human P-gp membranes at $37^{\circ} \mathrm{C}$ for $45 \mathrm{~min}$. The luminescence signal was started by adding ATP detection buffer. After incubation at room temperature for $25 \mathrm{~min}$, the samples were read in white 96-well plates on a multi-plate reader (BIOTEK).

\section{Conclusions}

Compounds 1-3 were designed and synthesized based on a trans-2-aminocyclohexan-1-ol structure. Previous investigations have indicated the anticonvulsant potency of these compounds. Additionally, in vitro metabolism of 1-3 via liver microsomes and a microbial model (Cunninghamella) was performed. To complement the above results, in the present study the safety profile of both enantiomers and a racemate (1-3) was evaluated, including their cytotoxicity, mutagenicity, and reactive metabolite formation potential. Moreover, their antimutagenic activity and the effect on P-gp ATPase were examined.

The obtained results revealed that the newly synthesized active chiral $\mathrm{N}$-aminoalkyl derivatives of trans-2-aminocyclohexan-1-ol may be promising candidates for further research focused on the discovery and development of anticonvulsant agents. All tested compounds demonstrated their promising anticancer properties on the glioblastoma cells U373. Furthermore, the P-gp ATPase assay demonstrated that both enantiomers are potent P-gp inhibitors as they inhibit P-gp ATPase activity. This new application of compounds 1-3 is also attractive due to their mutagenic safety, low bioactivation potential, and important antimutagenic activity. These results might be of great potential interest in the design of new antiepileptic compounds.

Finally, our study indicated the similar safety profile of the enantiomeric $\mathrm{N}$-aminoalkyl derivatives of trans-2-aminocyclohexan-1-ol, although in the previous studies both enantiomers differ in their biotransformation pathways and pharmacological activity.

Author Contributions: Data curation, P.K.; Formal analysis, P.K. and K.S.; Funding acquisition, E.P. and K.S.; Investigation, P.K., K.K., K.P., K.S., B.P., K.W.-P., and M.W.-K.; Methodology, P.K. and K.S.; Supervision, E.P. and K.S.; Validation, E.P. and P.K.; Visualization, P.K. and K.W.-P.; Writing-Original Draft, P.K. and K.S.; Writing-Review and Editing, K.S.

Funding: This research was funded by Jagiellonian University Medical College, grant numbers K/ZDS/007826 and K/DSC/005332.

Acknowledgments: We would like to dedicate this work to the memory of Jan Krzek, Dean of the Faculty of Pharmacy JU MC in the years 2010-2015.

Conflicts of Interest: The authors declare no conflict of interest.

\section{References}

1. Bialer, M.; White, H.S. Key factors in the discovery and development of new antiepileptic drugs. Nat. Rev. Drug Discov. 2010, 9, 68-82. [CrossRef] [PubMed]

2. Froscher, W. Drug resistant epilepsy. J. Epileptol. 2012, 20, 17-23.

3. Xiong, J.; Mao, D.A.; Liu, L.Q. Research progress on the role of ABC transporters in the drug resistance mechanism of intractable epilepsy. Biomed. Res. Int. 2015, 19, 45-51. [CrossRef] [PubMed]

4. Dalic, L.; Cook, M.J. Managing drug-resistant epilepsy: Challenges and solutions. Neuropsychiatr. Dis. Treat. 2016, 12, 2605-2616. [CrossRef] [PubMed]

5. Feldmann, M.; Koepp, M. ABC transporters and drug resistance in patients with epilepsy. Curr. Pharm. Des. 2016, 22, 5793-5807. [CrossRef] [PubMed]

6. Muth, E.A.; Haskins, J.T.; Moyer, J.A.; Husbands, G.E.; Nielsen, S.T.; Sigg, E.B. Antidepressant biochemical profile of the novel bicyclic compound Wy-45,030, an ethyl cyclohexanol derivative. Biochem. Pharmacol. 1986, 35, 4493-4497. [CrossRef] 
7. Jesse, C.R.; Bortolatto, C.F.; Savegnago, L.; Rocha, J.B.; Nogueira, C.W. Involvement of L-arginine-nitric oxide-cyclic guanosine monophosphate pathway in the antidepressant-like effect of tramadol in the rat forced swimming test. Prog. Neuropsychopharmacol. Biol. Psychiatry 2008, 32, 1838-1843. [CrossRef] [PubMed]

8. Pekala, E.; Marona, H. Estimating the lipophilicity of a number of 2-amino-1-cyclohexanol derivatives exhibiting anticonvulsant activity. Biomed. Chromatogr. 2009, 23, 543-550. [CrossRef] [PubMed]

9. Kubowicz, P.; Marona, H.; Pękala, E. Synthesis, anticonvulsant activity and metabolism of 4-chlor-3-methylphenoxyethylamine derivatives of trans-2-aminocyclohexan-1-ol. Chirality 2015, 27, 163-169. [CrossRef] [PubMed]

10. Lippi, G.; Fernandes, C.C.; Ewell, L.A.; John, D.; Romoli, B.; Curia, G.; Taylor, S.R.; Frady, E.P.; Jensen, A.B.; Liu, J.C.; et al. MicroRNA-101 regulates multiple developmental programs to constrain excitation in adult neural networks. Neuron 2016, 92, 1337-1351. [CrossRef] [PubMed]

11. Mahringer, A.; Fricker, G. ABC transporters at the blood-brain barrier. Expert Opin. Drug Metab. Toxicol. 2016, 12, 499-508. [CrossRef] [PubMed]

12. Luna-Tortós, C.; Fedrowitz, M.; Löscher, W. Several major antiepileptic drugs are substrates for human P-glycoprotein. Neuropharmacology 2008, 55, 1364-1375. [CrossRef] [PubMed]

13. Luna-Tortós, C.; Rambeck, B.; Jürgens, U.H.; Löscher, W. The antiepileptic drug topiramate is a substrate for human P-glycoprotein but not multidrug resistance proteins. Pharm. Res. 2009, 26, 2464-2470. [CrossRef] [PubMed]

14. Zhang, C.; Kwan, P.; Zu, Z.; Baum, L. The transport of antiepileptic drugs by P-glycoprotein. Adv. Drug Deliv. Rev. 2012, 64, 930-942. [CrossRef] [PubMed]

15. Amin, M.L. P-glycoprotein Inhibition for Optimal Drug Delivery. Drug Target Insights 2013, 7, 27-34. [CrossRef] [PubMed]

16. Finsterer, J.; Scorza, F.A. Effects of antiepileptic drugs on mitochondrial functions, morphology, kinetics, iogenesis, and survival. Epilepsy Res. 2017, 136, 5-11. [CrossRef] [PubMed]

17. Na, L.; Wartenberg, M.; Nau, H.; Hescheler, J.; Sauer, H. Anticonvulsant valproic acid inhibits cardiomyocyte differentiation of embryonic stem cells by increasing intracellular levels of reactive oxygen species. Birth Defects Res. A Clin. Mol. Teratol. 2003, 67, 174-180. [CrossRef]

18. Ahir, B.K.; Pratten, M.K. Developmental cardiotoxicity effects of four commonly used antiepileptic drugs in embryonic chick heart micromass culture and embryonic stem cell culture systems. Toxicol. In Vitro 2014, 28, 948-960. [CrossRef]

19. Kudin, A.P.; Mawasi, H.; Eisenkraft, A.; Elger, C.E.; Bialer, M.; Kunz, W.S. Mitochondrial Liver Toxicity of Valproic Acid and Its Acid Derivatives Is Related to Inhibition of $\alpha$-Lipoamide Dehydrogenase. Int. J. Mol. Sci. 2017, 18, 1912. [CrossRef] [PubMed]

20. Hebert, S.A.; Bohan, T.P.; Erikson, C.L.; Swinford, R.D. Thrombotic microangiopathy associated with Valproic acid toxicity. BMC Nephrol. 2017, 18, 262. [CrossRef] [PubMed]

21. Sofroniew, M.V.; Vinters, H.V. Astrocytes: Biology and pathology. Acta Neuropathol. 2010, 119, 7-35. [CrossRef] [PubMed]

22. Gualtieri, F.; Curia, G.; Marinelli, C.; Biagini, G. Increased perivascular laminin predicts damage to astrocytes in CA3 and piriform cortex following chemoconvulsive treatments. Neuroscience 2012, 218, 278-294. [CrossRef] [PubMed]

23. Curia, G.; Lucchi, C.; Vinet, J.; Gualtieri, F.; Marinelli, C.; Torsello, A.; Constantino, L.; Biagini, G. Pathophysiogenesis of mesial temporal lobe epilepsy: Is prevention of damage antiepileptogenic? Curr. Med. Chem. 2014, 21, 663-688. [CrossRef] [PubMed]

24. Rapacz, A.; Waszkielewicz, A.M.; Pańczyk, K.; Pytka, K.; Koczurkiewicz, P.; Piska, K.; Pękala, E.; Budziszewska, B.; Starek-Śmiechowicz, B.; Marona, H. Design, synthesis and anticonvulsant-analgesic activity of new $\mathrm{N}$-[(phenoxy)alkyl]- and $\mathrm{N}$-[(phenoxy)ethoxyethyl]aminoalkanols. MedChemComm 2016, 8, 220-238. [CrossRef] [PubMed]

25. Coccini, T.; Caloni, F.; Ramírez Cando, L.J.; De Simone, U. Cytotoxicity and proliferative capacity impairment induced on human brain cell cultures after short- and long-term exposure to magnetite nanoparticles. J. Appl. Toxicol. 2017, 37, 361-373. [CrossRef] [PubMed]

26. Lian, D.; Chonghua, Z.; Wen, G.; Hongwei, Z.; Xuetau, B. Label-free and dynamic monitoring of cytotoxicity to the blood-brain barrier cells treated with nanometre copper oxide. IET Nanobiotechnol. 2017, 11, 948-956. [CrossRef] [PubMed] 
27. Pańczyk, K.; Żelaszczyk, D.; Koczurkiewicz, P.; Słoczyńska, K.; Pękala, E.; Żesławska, E.; Nitek, W.; Żmudzki, P.; Marona, H.; Waszkielewicz, A. Synthesis and anticonvulsant activity of phenoxyacetyl derivatives of amines, including aminoalkanols and amino acids. MedChem Comm 2018, 9, 1933-1948. [CrossRef]

28. Matysiak, S.; Chmiel, A.; Skolimowski, J.; Kula, J.; Pasternak, B.; Blaszczyk, A. Synthesis and cytotoxicity of (R)- and (S)-ricinoleic acid amides and their acetates. Chirality 2017, 29, 616-622. [CrossRef]

29. Sun, Q.; Mao, R.; Wang, D.; Hu, C.; Zheng, Y.; Sun, D. The cytotoxicity study of praziquantel enantiomers. Drug Des. Devel. Ther. 2016, 10, 2061-2068. [CrossRef]

30. Tokunaga, E.; Akiyama, H.; Soloshonok, V.A.; Inoue, Y.; Hara, H.; Shibata, N. Biological evaluation of both enantiomers of fluoro-thalidomide using human myeloma cell line H929 and others. PLoS ONE 2017, 12, e0182152. [CrossRef]

31. Tarasenko, N.; Cutts, S.M.; Phillips, D.R.; Berkovitch-Luria, G.; Bardugo-Nissim, E.; Weitman, M.; Nudelman, A.; Rephaeli, A. A novel valproic acid prodrug as an anticancer agent that enhances doxorubicin anticancer activity and protects normal cells against its toxicity in vitro and in vivo. Biochem. Pharmacol. 2014, 15, 158-168. [CrossRef] [PubMed]

32. Kwiecińska, P.; Taubøll, E.; Grzyb, E.; Fiedor, E.; Ptak, A.; Gregoraszczuk, E.L. Valproic Acid as a Promising Co-Treatment with Paclitaxel and Doxorubicin in Different Ovarian Carcinoma Cell Lines. Int. J. Gynecol. Cancer 2016, 26, 1546-1556. [CrossRef] [PubMed]

33. Leung, L.; Kalgutkar, A.S.; Obach, R.S. Metabolic activation in drug induced liver injury. Drug Metab. Rev. 2012, 44, 18-33. [CrossRef] [PubMed]

34. Pessayre, D.; Fromenty, B.; Berson, A.; Robin, M.A.; Letteron, P.; Moreau, R.; Mansouri, A. Central role of mitochondria in drug-induced liver injury. Drug Metab. Rev. 2012, 44, 34-87. [CrossRef] [PubMed]

35. Sadeque, A.J.; Fisher, M.B.; Korzekwa, K.R.; Gonzalez, F.J.; Rettie, A.E. Human CYP2C9 and CYP2A6 mediate formation of the hepatotoxin 4-ene-valproic acid. J. Pharmacol. Exp. Ther. 1997, 282, 698-703.

36. Dalvie, D.; Kalgutkar, A.S.; Chen, W. Practical approaches to resolving reactive metabolite liabilities in early discovery. Drug Metab. Rev. 2015, 47, 56-70. [CrossRef] [PubMed]

37. Lassila, T.; Mattila, S.; Turpeinen, M.; Tolonen, A. Glutathione trapping of reactive drug metabolites produced by biomimetic metalloporphyrin catalysts. Rapid Commun. Mass Spectrom. 2015, 30, 521-532. [CrossRef]

38. Gómez-Lechón, M.J.; Tolosa, L.; Donato, M.T. Metabolic activation and drug-induced liver injury: In vitro approaches for the safety risk assessment of new drugs. J. Appl. Toxicol. 2016, 36, 752-768. [CrossRef]

39. Migliore, L.; Coppedč, F. Genetic and environmental factors in cancer and neurodegenerative diseases. Mutat. Res. 2002, 512, 135-153. [CrossRef]

40. Smith, S.W. Chiral toxicology: it's the same thing ... only different. Toxicol. Sci. 2009, 110, 4-30. [CrossRef]

41. Słoczyńska, K.; Powroźnik, B.; Pękala, E.; Waszkielewicz, A.M. Antimutagenic compounds and their possible mechanisms of action. J. Appl. Genet. 2014, 55, 273-285. [CrossRef] [PubMed]

42. Fronza, G.; Campomenosi, P.; Iannone, R.; Abbondandol, A. The 4-nitroquinoline 1 oxide mutational spectrum in single stranded DNA is characterized by guanine to pyrimidine transversions. Nucleic Acids Res. 1992, 20, 1283-1287. [CrossRef] [PubMed]

43. Ajith, T.A.; Soja, M.A. Comparative study on the antimutagenicity of atorvastatin and lovastatin against directly acting mutagens. Cell Biol. Toxicol. 2006, 22, 269-274. [CrossRef] [PubMed]

44. Ambudkar, S.V.; Dey, S.; Hrycyna, C.A.; Ramachandra, M.; Pastan, I.; Gottesman, M.M. Biochemical, cellular and pharmacological aspects of the multidrug transporter. Annu. Rev. Pharmacol. Toxicol. 1999, 39, 361-398. [CrossRef] [PubMed]

45. Schinkel, A.H.; Jonker, J.W. Mammalian drug efflux transporters of the ATP binding cassette (ABC) family: An overview. Adv. Drug Deliv. Rev. 2003, 55, 3-29. [CrossRef]

46. Nobili, S.; Landini, I.; Giglioni, B.; Mini, E. Pharmacological strategies for overcoming multidrug resistance. Curr. Drug Targets 2006, 1, 861-879. [CrossRef]

47. Aller, S.G.; Yu, J.; Ward, A.; Weng, Y.; Chittaboina, S.; Zhuo, R.; Harrell, P.M.; Trinh, Y.T.; Zhang, Q.; Urbatsch, I.L.; et al. Structure of P-glycoprotein reveals a molecular basis for poly-specific drug binding. Science 2009, 27, 1718-1722. [CrossRef]

48. Zhou, Q.; Yu, L.S.; Zeng, S. Stereoselectivity of chiral drug transport: A focus on enantiomer- transporter interaction. Drug Metab. Rev. 2014, 46, 283-290. [CrossRef]

49. Zhang, Q.; Zhang, M.; Wang, D.; Zhao, Y.; Yu, Z. Comparison of intestinal permeability and p-glycoprotein effects on the intestinal absorption of enantiomers of 2-(2-hydroxypropanamido) benzoic acid in rats. Chirality 2017, 29, 26-32. [CrossRef] 
50. Lopes, A.; Martins, E.; Silva, R.; Pinto, M.M.M.; Remião, F.; Sousa, E.; Fernandes, C. Chiral Thioxanthones as Modulators of P-glycoprotein: Synthesis and Enantioselectivity Studies. Molecules 2018, 23, 626. [CrossRef]

51. Pham, Y.T.; Régina, A.; Farinotti, R.; Couraud, P.O.; Wainerm, I.W.; Roux, F.; Gimenez, F. Interactions of racemic mefloquine and its enantiomers with P-glycoprotein in an immortalised rat braincapillary endothelial cell line, GPNT. Biochim. Biophys. Acta 2000, 1524, 212-219. [CrossRef]

52. Shen, S.; He, Y.; Zeng, S. Stereoselective regulation of mdr1 expression in caco-2 cells by cetirizine enantiomers. Chirality 2007, 19, 485-490. [CrossRef]

53. Hu, Z.; Zhou, Z.; Hu, Y.; Wu, J.; Li, Y.; Huang, W. HZ08 reverse P-glycoprotein mediated multidrug resistance in vitro and in vivo. PLOS ONE 2015, 10, 68-86. [CrossRef] [PubMed]

54. Löscher, W.; Luna-Tortós, C.; Römermann, K.; Fedrowitz, M. Do ATP-binding cassette transporters cause pharmacoresistance in epilepsy? Problems and approaches in determining which antiepileptic drugs are affected. Curr. Pharm. Des. 2011, 17, 2808-2828. [CrossRef] [PubMed]

55. Ren, F.; Shen, J.; Shi, H.; Hornicek, F.J.; Kan, Q.; Duan, Z. Novel mechanisms and approaches to overcome multidrug resistance in the treatment of ovarian cancer. Biochim. Biophys. Acta 2016, 1866, 266-275. [CrossRef]

56. Dewanjee, S.; Dua, T.K.; Bhattacharjee, N.; Das, A.; Gangopadhyay, M.; Khanra, R.; Joardar, S.; Riaz, M.; Feo, V.; Zia-Ul-Haq, M. Natural products as alternative choices for P-glycoprotein (P-gp) inhibition. Molecules 2017, 22, 871. [CrossRef]

57. Joshi, P.; Vishwakarma, R.A.; Bharate, S.B. Natural alkaloids as P gp inhibitors for multidrug resistance reversal in cancer. Eur. J. Med. Chem. 2017, 138, 273-292. [CrossRef]

58. Kambli, L.; Bhatt, L.K.; Oza, M.; Prabhavalkar, K. Novel therapeutic targets for epilepsy intervention. Seizure 2017, 51, 27-34. [CrossRef]

59. Yu, J.; Mathisen, D.E.; Burdette, D.; Brown, D.G.; Becker, C.; Aharony, D. Identification of multiple glutathione conjugates of 8-amino-2-methyl-4-phenyl-1,2,3,4-tetrahydroisoquinoline maleate (nomifensine) in liver microsomes and hepatocyte preparations: Evidence of the bioactivation of nomifensine. Drug Metab. Dispos. 2010, 38, 46-60. [CrossRef]

60. Maron, D.M.; Ames, B.N. Revised methods for the Salmonella mutagenicity test. Mutat. Res. 1983, 4, $173-215$. [CrossRef]

61. Mortelmans, K.; Zeiger, E. The Ames Salmonella/microsome mutagenicity assay. Mutat. Res. 2000, 455, 29-60. [CrossRef]

62. Gulluce, M.; Agar, G.; Baris, O.; Karadayi, M.; Orhan, F.; Sahin, F. Mutagenic and antimutagenic effects of hexane extract of some Astragalus species grown in the eastern Anatolia region of Turkey. Phytother. Res. 2010, 24, 1014-1018. [PubMed]

63. Czyż, A.; Jasiecki, J.; Bogdan, A.; Szpilewska, H.; Weggrzyn, G. Genetically modified Vibrio harveyi strains as potential bioindicators of mutagenic pollution of marine environments. Appl. Environ. Microbiol. 2000, 66, 599-605. [CrossRef]

64. Podgórska, B.; Chęć, E.; Ulanowska, K.; Wegrzyn, G. Optimisation of the microbiological mutagenicity assay based on genetically modified Vibrio harveyi strains. J. Appl. Genet. 2005, 46, 241-246. [PubMed]

65. Słoczyńska, K.; Waszkielewicz, A.M.; Marona, H. Preliminary assessment of mutagenic and anti-mutagenic potential of some aminoalkanolic derivatives of xanthone by use of the Vibrio harveyi assay. Mutat. Res. Genet. Toxicol. Environ. Mutagen. 2014, 21, 8-13. [CrossRef] [PubMed]

66. Evandri, M.G.; Battinelli, L.; Daniele, C.; Mastrangelo, S.; Bolle, P.; Mazzanti, G. The antimutagenic activity of Lavandulaangustifolia (lavender) essential oil in the bacterial reverse mutation assay. Food Chem. Toxicol. 2005, 43, 1381-1387. [CrossRef] [PubMed]

67. Resende, F.A.; Barbosa, L.C.; Tavares, D.C.; de Camargo, M.S.; de Souza Rezende, K.C.; E Silva, M.L.; Varanda, E.A. Mutagenicity and antimutagenicity of (-)-hinokinin a trypanosomicidal compound measured by Salmonella microsome and comet assays. BMC Complement. Altern. Med. 2012, 12, 203. [CrossRef]

Sample Availability: Samples of the compounds 1-3 are available from the authors. 